原著論文

\title{
臼歯部人工歯の摩耗が水平被蓋および小窩裂溝におよぼす影響
}

\author{
千葉 ひかり
}

\section{Influence of Wearing Artificial Teeth on Horizontal Overlap and Occlusal Surface Fissures}

Hikari Chiba, DMD

\begin{abstract}
抄 録
目的：義歯機能を長期に保持するためには，摩耗が生じても咀嚼機能を損なわない人工歯が必要である. 本研究は摩耗による臼歯部人工歯の形態変化を観察し，水平被蓋と小窩裂溝の経時的変化について検討し た.

方法：実験試料として，アクリリックレジン歯 3 種，硬質レジン歯 3 種を選択した。上下顎第一小臼歯か ら第二大臼歯まで排列した試料を用い，水平移動式試験装置にて $8 \times 10^{4}$ 回まで摩耗試験を行った。計測 項目は水平被蓋部の投影面積, 小窩裂溝部の面積, 人工歯重量とし, 試験前および試験回数 $1 \times 10^{4}$ 回毎 に計測を行った。

結果：水平被蓋部面積の変化はアクリリックレジン歯と硬質レジン歯で有意差は認められなかった。小窩 裂溝部面積はすべての人工歯において $2 \times 10^{4}$ 回まで緩除な減少を示し， $5 \times 10^{4}$ 回以降では人工歯間に 有意差が認められた。バイオエースレジン歯 $20^{\circ}(\mathrm{A}-\mathrm{Bi})$, エンデュラポステリオ $(\mathrm{H}-\mathrm{En})$, 試作人工歯 $(\mathrm{H}-\mathrm{Tr})$ では摩耗後でも水平被蓋，小窩裂溝ともに保存される傾向にあった。全ての人工歯において，重量減少率 は人工歯間で異なった。

結論：人工歯の硬度に依らず，水平被蓋と煩舌径と小窩裂溝が十分に付与されている人工歯が摩耗後にも 水平被蓋および小窩裂溝が保存されることが示唆された。
\end{abstract}

和文キーワード

臼歯部人工歯，摩耗試験，水平被蓋，小窩裂溝，咬傷

\section{I 。緒言}

有床義歯における四歯部人工歯の役割は, 歯列欠損に 対する咬合位の保持と咀嚼機能の回復にある。しかし義 歯を長期に使用すると，人工歯の摩耗は進行し，咬合の 不調和 ${ }^{1-3)}$ を生じる。この咬合関係の変化は, 義歯の動 摇や顎堤の疼痛を引き起こすばかりでなく，顎関節や審 美にも影響すると考えられる。また咬合高径の減少，小 窩裂溝や水平被蓋の減少は咀嚼能率を低下させ，咬傷な ぞを生じる原因となる，義歯機能を長期に保全するため に，現在，市販されている人工歯の問題点を抽出し，摩
耗が生じても機能を損なわない人工歯およびその形態 について検討する必要がある。人工歯が摩耗しても義歯 の機能を損なうことなく長期に使用できることは，特に 高齢義歯装着者の QOL において重要であると考える.

先人による人工歯の材質と摩耗状況に関する研究の 歴史は古い. 阿部ら ${ }^{4,5)}$ は第一小臼歯部のレジン歯, 硬 質レジン歯, 陶歯, 金属歯, 天然歯と平板試料における 摩耗試験を行い, 摩耗量を重量, 高さ, 深さ, 表面粗さ で表し， 刍歯部人工歯材料の選択基準を検討している. Koczorowski ら ${ }^{6)}$ は金属歯とレジン歯の組み合せによ る平板試料での摩耗試験を行い, 摩耗量を体積の減少量 で表している。辻ら ${ }^{7)}$ は既製の陶歯，レジン歯にて摩

鶴見大学歯学部歯科補綴学第一講座

Department of Removable Prosthodontics, Tsurumi University School of Dental Medicine

受付 : 2008 年 10 月 22 日/受理 : 2008 年 12 月 29 日

Received on October 22, 2008/Accepted on December 29, 2008 
耗試験を行い, 摩耗量を高さと体積の減少量で比較して いる.

これまでの報告の多くは陶歯，レジン歯，硬質レジン 歯, 金属歯, 天然歯の各組み合わせにおける摩耗量を比 較し, 高さ, 深さの減少，表面粗さや輪郭形状の変化で 表している ${ }^{8-13)}$ 。これに対し, 摩耗後の人工歯形態, 水 平被蓋の変化, 小窩裂溝の形態変化について報告したも のはない.

本研究は摩耗後にも水平被蓋と小窩裂溝が確保され, 機能的形態が保持される人工歯について検証すること を目的とし，湿潤下で水平滑走運動が可能な摩耗試験 装置を製作し，歯列対歯列で摩耗試験を行い，経時的 な水平被蓋および小窩裂溝の変化と人工歯の重量を観 察した。

\section{II. 方 法}

\section{1. 材料}

義歯の臨床においては市販の既製人工歯を使用する 頻度が高い ${ }^{14)}$ 。そこで市場分析調査（アールアンド ディ） ${ }^{15)}$ から，使用頻度の高いアクリリックレジン臼 歯 3 種と硬質レジン臼歯 3 種を選択した（表 1 )。試作 人工歯は現在，当教室で開発中の硬質レジン歯である. 各人工歯は第一小臼歯から第二大臼歯までを選択した。 図 1 は各人工歯の咬合面形態と第一大臼歯における嵌 合状態を近心方向から観察したものを示す.

\section{2、摩耗試験装置}

本研究を遂行するため独自に摩耗試験装置 (TM-SC2, 日本メック）を開発，作製した。この装置は水平滑走を 行う移動式摩耗試験装置であり，口腔内環境を考慮し， 湿潤下での試験を行える設計とした（図 2)。人工歯を 排列した試料の摩耗試験装置への付着は金型試料台を 介して行った。摩耗試験装置の作動原理は，ギア付き速 度調整モーターの回転がカムを利用し，回転軸を介して リングバーを回転させることで，上部金型試料台に対し て平行に下部金型試料台を左右滑走移動させる。また一 定温度の水中で摩耗試験を行えるよう,循環ポンプ・サー モスタット付属の恒温水槽を設置した。本装置は 5 機 連動式で，同時に 5 組の試料の摩耗試験が可能である. 摩耗条件は荷重 $1.5 \mathrm{kgf}$ ，移動ストロークは煩舌方向に

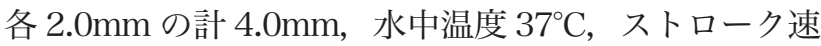
度 60 回 / 分を 1 サイクルとした。義歯研磨材として使 用される白土砂 (干切白土, 丸中白土) を粉液重量比 1 : 1 で水に混和し，磨材として使用した。
表 $1 \quad$ Materials

材料

\begin{tabular}{|c|c|c|c|c|c|c|}
\hline Materials & Products & Code & Mould & $\begin{array}{l}\text { The gross width of } \\
\text { unilateral artificial } \\
\text { molar }(\mathrm{mm})\end{array}$ & $\begin{array}{l}\mathrm{f} \\
\text { I Cusp } \\
\text { angle }\end{array}$ & Manufacturers \\
\hline \multirow[t]{3}{*}{ Acrylic resin } & BioACE & $\mathrm{A}-\mathrm{Bi}$ & $28 \mathrm{M}$ & $\begin{array}{l}\mathrm{U}: 28.0 \\
\mathrm{~L}: 30.5\end{array}$ & 20 & Shofu \\
\hline & $\begin{array}{ll}\text { LIVEDENT } & \text { FB20 } \\
\text { Plastic } 100 & \end{array}$ & A-Li & $28 \mathrm{M}$ & $\begin{array}{l}\text { U: } 28.0 \\
\text { L: } 30.0\end{array}$ & 20 & GC \\
\hline & Púre & $\mathrm{A}-\mathrm{Pu}$ & $28 \mathrm{M}$ & $\begin{array}{l}\text { U: } 28.0 \\
\text { L: } 29.8\end{array}$ & 20 & QEST \\
\hline \multirow[t]{3}{*}{ Hard acrylic resin } & $\begin{array}{l}\text { ENDURA } \\
\text { POSTERIO }\end{array}$ & H-En & $28 \mathrm{M}$ & $\begin{array}{l}\text { U: } 28.0 \\
\text { L: } 30.5\end{array}$ & 20 & $\begin{array}{l}\text { Shofu } \\
\text { Yamahachi }\end{array}$ \\
\hline & SOLUUT PX & H-So & $28 \mathrm{M}$ & $\begin{array}{l}\mathrm{U}: 28.0 \\
\mathrm{~L}: 30.0\end{array}$ & 20 & $\begin{array}{l}\text { DENTAL } \\
\text { MFG,CO }\end{array}$ \\
\hline & Trial & $\mathrm{H}-\mathrm{Tr}$ & $28 \mathrm{M}$ & $\begin{array}{l}\text { U: } 27.8 \\
\text { L: } 29.8\end{array}$ & 20 & NISSIN \\
\hline
\end{tabular}

(1)

(2)

(3)

(4)

(5)
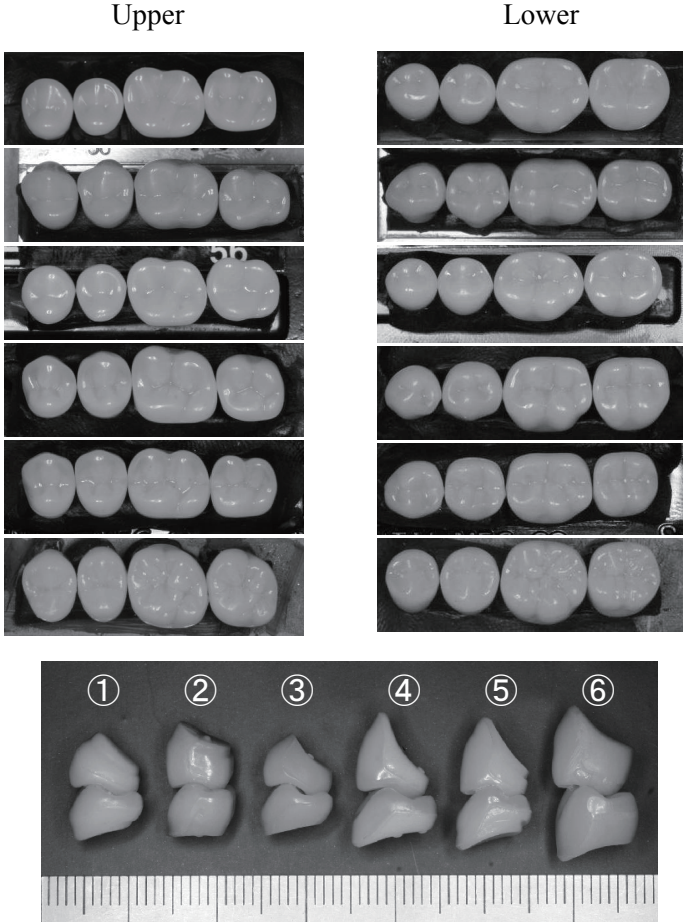

図 1 Form and occlusal relations of each artificial teeth

The under picture was occlusal relations about the first molars of each artificial teeth from mesial side. (1) BioACE (2) LIVDENT FB20 Plastic100 (3) Púre (4) ENDURA POSTERIO (5) SOLUUT PX (6) Trial 各人工歯の形態と嵌合状態

\section{3、試料製作方法}

試料の製作は本学歯学部全部床義歯学模型実習 ${ }^{16)}$ に おいて，フルバランスド・オクルージョンを付与して製 作した上下顎全部床義歯を咬合器（ProArch II G, 松風） に取り付け，臼歯部人工歯の排列位置を基準に上下顎第 一小臼歯から第二大鼠までの 4 歯を排列した（図 3). 


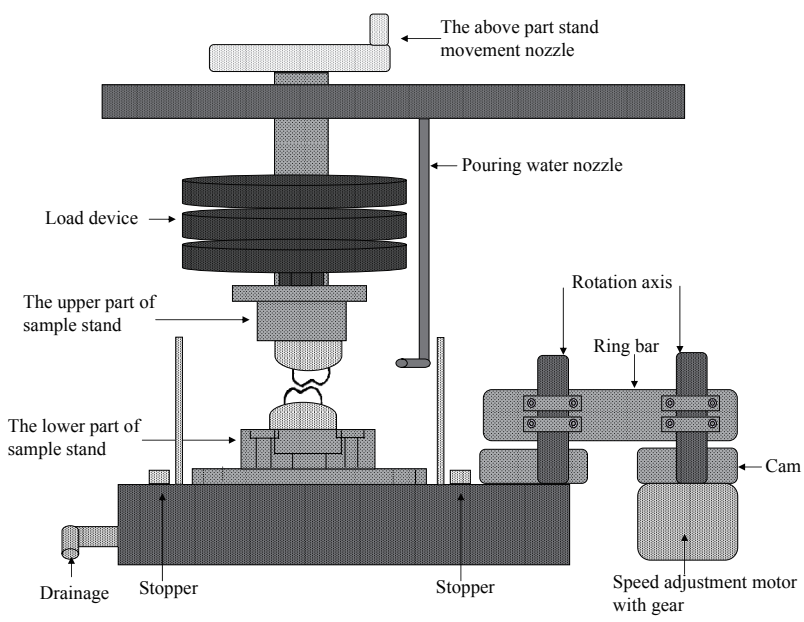

図 2 Structure of the wear testing device 摩耗試験装置の構造

排列した人工歯は，義歯床用加熱重合レジン（ACRON MC, ジーシー) にて重合し，義歯床と一体化した試料 を完成した。排列した人工歯の咬合面コアを超硬質石膏 (NEW FUJIROCK，ジーシー）にて採得し，同じ人工 歯で同一の排列となるょう配慮した，以上の方法で試料 を 5 組ずつ計 30 組製作した。試料は咬合器上と同一の 位置関係で摩耗試験装置に取り付けた。

\section{4. 測定方法}

試料の計測項目は水平被蓋部の投影面積，小窩裂溝の 面積, 人工歯の重量とした。試料の計測は試験前および 試験回数 $1 \times 10^{4}$ 回毎とし, $8 \times 10^{4}$ 回まで行った。ま た人工歯表面のビッカース硬度の計測を行った。

1）水平被蓋部投影面積の計測

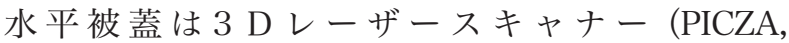
Roland）により人工歯煩側の被蓋を測定し，面積で表 示した。レーザー照射角度は図 4 に示すように，上下 顎歯列が嵌合状態で歯軸に対して 25 度，歯列に対して 90 度と規定し，治具を用いて計測条件が同一になるよ う配慮した。得られた画像を図 5 に示す。下顎人工歯 の煩側面から上顎人工歯の咬合面方向を観察した図の 白抜き部分を水平被蓋部の面積として計測した。計測範 囲は上顎人工歯咬合面と㚘側面の境界を連ねた線と，下 顎人工歯煩側面の画像上における最大豊隆部を連ねた 線に囲まれる範囲に設定した。

各人工歯における面積の経時的変化は，試験前の面 積を $100 \%$ とし，試験回数 $1 \times 10^{4}$ 回毎にその比率で 表した。

2）小窩裂溝部面積の計測

上下顎人工歯間にホワイト・シリコーン

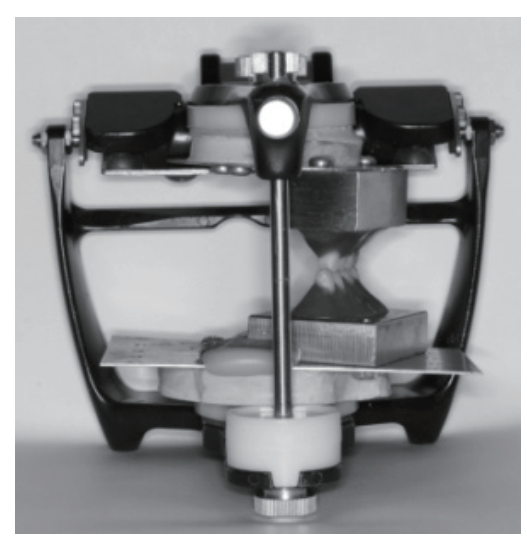

図 3 Arrangement of artificial teeth on the articulator 咬合器上での人工歯排列

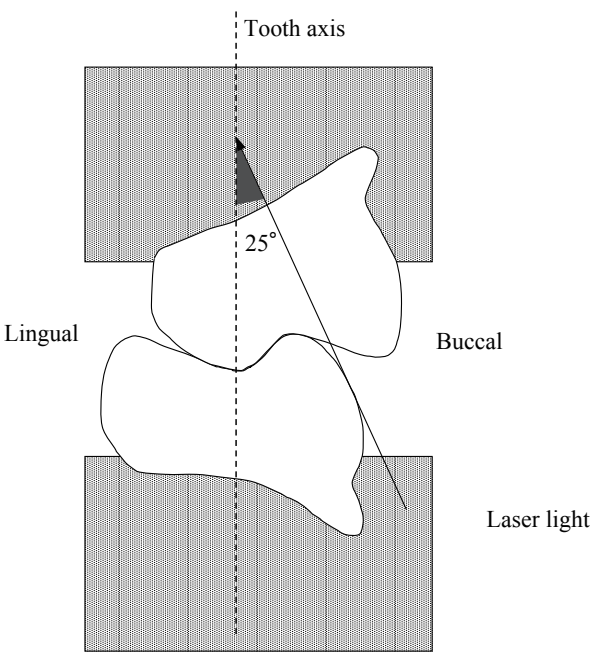

図 4 Scheme of irradiation angle of laser light レーザー光照射角度の模式図

CHECKER，ジーシー）を介在し，嵌合位において咬合 面を印記した。印記されたホワイト・シリコーン試料は シャウカステン上でデジタルカメラ (EOS Kiss Digital $\mathrm{N}$ ，Canon）を用い，撮影条件 Av（絞り数值）F7.1, 露出補正 0 , ISO 感度 400 で写真撮影を行った。得ら れた撮影試料は Photoshop にて閾值 122 で二階調化処 理を施し，黒化した部分を小窩裂溝部の面積とし，PC 上で計測した（図 6).

各人工歯における面積の経時的変化は, 試験前の面 積を $100 \%$ とし, 試験回数 $1 \times 10^{4}$ 回毎にその比率で 表した。

3）人工歯重量の計測

重量の計測は電子上血天秤 (LIBROR AEG-45SM, 
SHIMADZU) を用い, 各試料について 5 回ずつ行つた。 試料は試験回数 $1 \times 10^{4}$ 回毎に水洗し, $37^{\circ} \mathrm{C}$ のデシケー 夕中で 24 時間乾燥させた後, 計量した。試料の総重量 からレジン部分を差し引くことにより人工歯の重量を 算出した。また経時的な重量変化は試験回数 $1 \times 10^{4}$ 回 毎に元の重量に対する比率で表した。

4）人工歯表面のビッカース硬度の計測

試作人工歯のビッカース硬度（Hv）を計測した。硬 さ試験機（HMV-1，SHIMAZU）を用いて荷重 245.2 $\mathrm{m} \mathrm{N}$ ，負荷時間 30 秒で 5 回測定し，その平均值を表面 硬度とした。その他の人工歯についてはメーカーの公表 值を参考にした。

\section{5. 統計解析}

水平被蓋部投影面積，小窩裂溝部面積ならびに重量の 各計測結果については, 人工歯の種類と試験回数で二元 配置分散分析を行い, Tukeyの多重比較検定により危 険率 5\% で有意差を判定した.

\section{III. 結 果}

\section{1. 水平被蓋部投影面積}

水平被蓋部面積の計測結果を図 7 に示す。試験前の 各人工歯の水平被蓋部面積は H-So が $27.45 \pm 0.91 \mathrm{~mm}^{2}$ と最大で，すべての硬質レジン歯の面積はアクリリック レジン歯より大きい值を示した。試験回数 $4 \times 10^{4}$ 回で は H-Tr，H-En，A-Bi はほぼ同等の面積を有し，有意差 は認められなかった。アクリリックレジン歯と硬質レジ ン歯のグループ間の比較では, 試験回数 $7 \times 10^{4}$ 回まで 硬質レジン歯の被蓋が大きく, 有意差が認められたが $(\mathrm{p}<0.05), 8 \times 10^{4}$ 回では有意差は認められなかった

摩耗による水平被蓋部投影面積の経時的変化を図 8 に示す。すべての人工歯において試験回数 $1 \times 10^{4}$ 回か ら $2 \times 10^{4}$ 回までの間で面積の比較的急な減少を示す が，その後は緩徐に推移した。試験回数 $6 \times 10^{4}$ 回以降 はすべての人工歯で面積は $20 \%$ 程度まで減少し, 人工 歯間で有意差は認められなかった。試験回数 $8 \times 10^{4}$ 回 では，全ての人工歯において元の面積の約 $8 \%$ まで減少 した.

\section{2. 小窩裂溝部面積}

小窩裂溝部面積の計測結果を図 9 に示す。試験回数 $4 \times 10^{4}$ 回では H-Tr, H-En, A-Bi はほぼ同等の面積 を有した。試験回数 $8 \times 10^{4}$ 回では H-Tr, H-En, A-Bi は溝が残存していたが, H-So, A-Li においてはほぼ消 失した.アクリリックレジン歯と硬質レジン歯のグルー

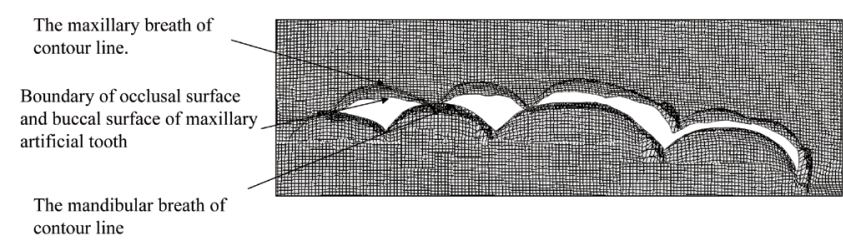

図 5 Range of measurement in projection area in the horizontal overlap 臼歯部人工歯の水平被蓋部における投影面積の計 測範囲

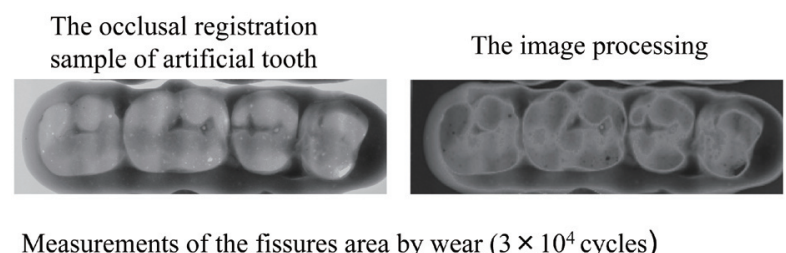

図 6 Measurement of the fissure area 小窩裂溝部の面積計測

プ間の比較では, すべての試験回数で有意差は認めら れなかった。

摩耗による小窩裂溝部面積の経時的変化を図 10 に示 す. H-Tr, H-En は試験開始から試験回数 $8 \times 10^{4}$ 回ま でほぼ一定の減少傾向を示した。他の人工歯では $2 \times$ $10^{4}$ 回以降 $5 \times 10^{4}$ 回まで急な減少を示し, その後再び 緩徐な減少を示す傾向であった。 $5 \times 10^{4}$ 回ではすべて の人工歯間で有意差が認められ $(\mathrm{p}<0.05), 8 \times 10^{4}$ 回で はH-Tr，H-En と他の人工歯間に有意差が認められた $(\mathrm{p}<0.05)$.

\section{3. 人工歯重量}

図 11 は摩耗による重量の経時的変化を比率で表示し た、いずれの人工歯においても $8 \times 10^{4}$ 回までほぼ均等 に減少したが, 減少率については人工歯間で異なった。 $4 \times 10^{4}$ 回において減少率が最も小さかったのはH-En で, $8 \times 10^{4}$ 回ではA-Liであった. A-Li, H-Tr, H-En は近似した減少傾向を示し, 減少率は少なく他の人工歯 との間に有意差が認められた $(\mathrm{p}<0.05)$. H-So の減少 率は最も大きく, $3 \times 10^{4}$ 回以降は他の人工歯との間に 有意差が認められた $(\mathrm{p}<0.05)$.

\section{4. 人工歯表面のビッカース硬度}

表 2 に人工歯表面のビッカース硬度の結果を示す。 アクリリックレジン歯は A-Bi が 20.5, A-Li が 21.0, 


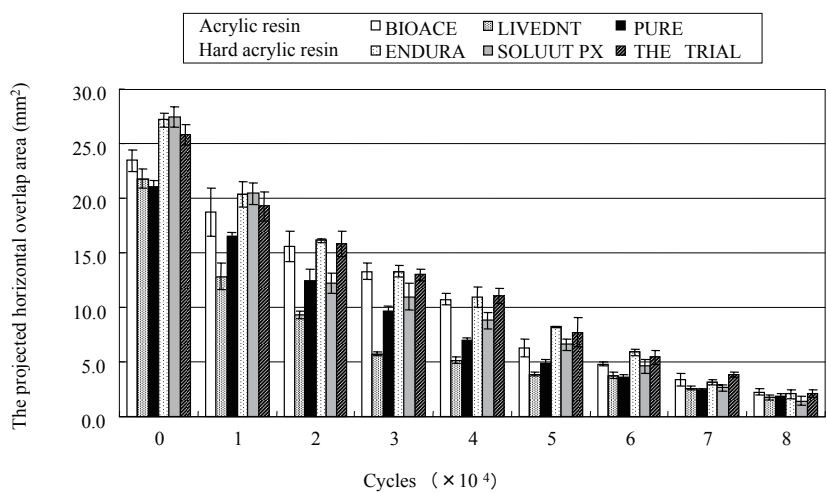

図 7 The projected horizontal overlap area of each artificial teeth by wear 水平被蓋部投影面積

A-Puが 20.5 で差は認められなかった，硬質レジン歯で は H-So が 45.0 と最大であり, 次いで H-Tr が 34.5, H-Enが 29.6 であった。

\section{IV. 考察}

1. 実験方法について

1）摩耗試験装置について

口腔内で生じる摩耗は咬合力，咬合様式，箸好食 物の違いなど多くの因子に影響される ${ }^{10,11,17)}$ 。この ため摩耗試験装置を用いた研究では，歯ブラシ摩耗 試験 ${ }^{18,19)}$, 摩擦摩耗試験，振動摩耗試験，衝撃滑走 摩耗試験 $\left.{ }^{4}, 5,7,20,21\right)$ など様々な方法により摩耗試験が 行われてきた。当教室で従来使用していた摩耗試験 装置 ${ }^{22,23)}$ は垂直落下と水平移動を行ういわゆる衝撃 滑走試験装置であった。衝撃滑走試験における衝突 摩耗機構は複雑で，衝撃力と滑走距離の設定におい て適正な組み合わせは困難であるとされている ${ }^{5,24)}$. さらに衝撃が人工歯の破損を招く可能性がある。歯 の摩耗は下顎の側方，前方，後方運動の中で側方運 動と最も密接な関係があることから ${ }^{25)}$ ，本研究では 下顎運動において側方運動を簡素化した水平移動式 を選択し，口腔内温度や湿潤状態など口腔内環境に 近似した新たな摩耗試験装置を考案，作製した。

2) 摩耗条件について

摩耗条件の設定において，荷重の設定は Harrison ら ${ }^{21)}$ の咀嚼時に歯牙に加わる力は $0.2 \sim 2 \mathrm{~kg}$ であるという 報告を参考にした。また予備実験を行い，荷重を増加さ せた場合，人工歯の磨耗量が著しかったため，基本荷重 $1.5 \mathrm{kgf}$ で実験を行った。移動スクロークの設定に関し, 藍 $^{26)}$ は咀嚼運動路にみられる側方滑走運動の範囲は切

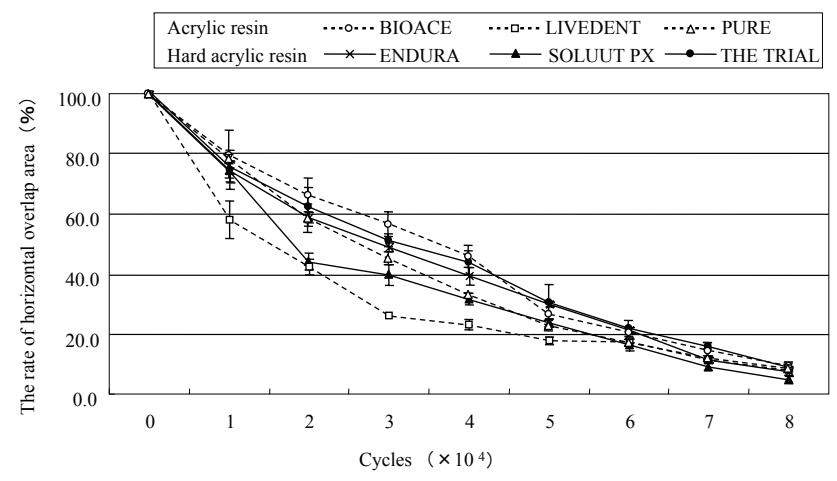

図 8 Duration of the projected horizontal overlap area of each artificial teeth by wear 摩耗による水平被蓋面積の経時的変化

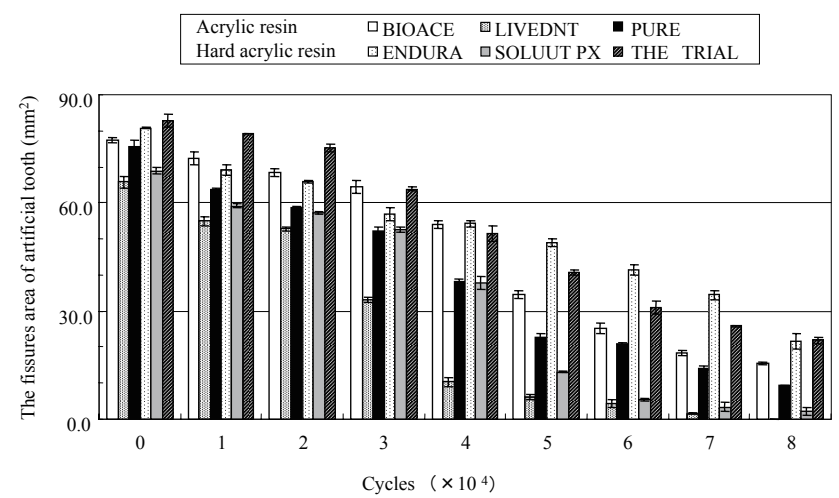

図 9 The fissures area of each artificial teeth by wear 小窩裂溝部面積

歯部で $1.0 \sim 6.0 \mathrm{~mm}$ の範囲にあり, 平均して 1.5 $4.0 \mathrm{~mm}$ 程度であるとし，臼歯部ではこの半分程度であ ると報告している。そこで本研究では，咬頭嵌合位から の移動ストロークを $2 \mathrm{~mm}$ と設定した。 また人工歯によ り㚘頁幅径が大きいものでは，摩耗の初期において上䕱 人工歯の煩側咬頭頂に接触は認められない。しかし設定 した滑走距離 $2 \mathrm{~mm}$ の範囲では，摩耗の進行とともに下 顎人工歯㚘側面と上顎人工歯の煩側咬頭頂の接触が認 められるようになり，すべての人工歯で上顎煩側咬頭頂 に至る摩耗が確認されたため, 移動ストロークは $2 \mathrm{~mm}$ で妥当性があると考えられた。

歯磨材や食品などの磨材を介在させるか否かについ てはこれまで相反的な意見が多く, 介在物のない二体摩 耗が多く行われている ${ }^{6,10,17)}$. しかしながら，摩耗が生 じる要因の一つに介在物の存在があることは明らかで ある ${ }^{14,27-29)}$. 本研究は摩耗の進行に伴う水平被蓋部面 積と小简裂溝部面積の推移を検討するため，磨材を使用 


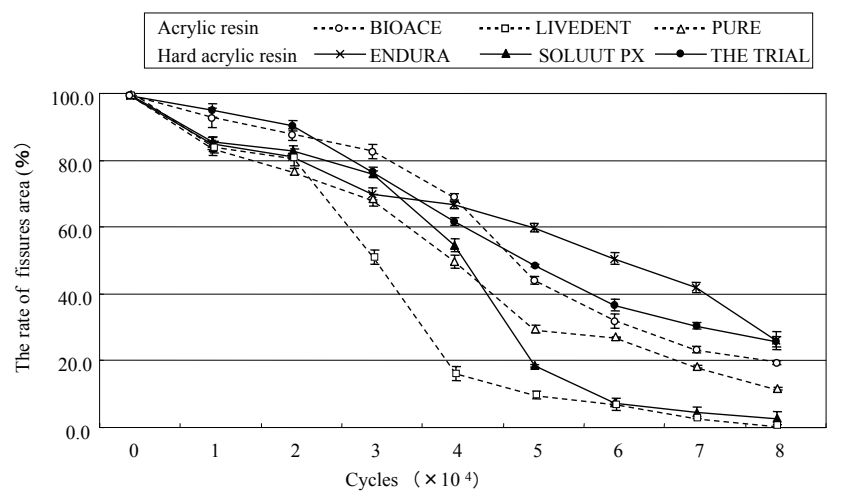

図 10 Duration of the fissures area of each artificial teeth by wear

摩耗による小窩裂溝部面積の経時的変化

し摩耗を促進させた。したがって, 本研究の試験回数に 対する摩耗量は，臨床における咀嚼回数と摩耗量の関係 と合致するものではない.

3）試料の製作について

過去の研究においては平板状，円柱状，半円状などの 試料や既製人工歯に加工を施した試料が用いられてき $た^{10,11,13,19,29-31)}$. 近年では，既製人工歯をそのままの 形態で使用している報告 ${ }^{27)}$ も散見されるが，一歯対一 歯で摩耗試験を行っているものがほとんどである。本研 究では口腔内で生じる摩耗に近似させ，かつ水平被蓋部 や小窩裂溝部の面積を検討する目的から上下顎の歯列 に咬合を付与し, 実験を行った。また歯列対歯列で摩耗 試験行うことにより，試験装置上での試料の安定を図っ た。この方法により, 摩耗が生じた後の咬合面形態を全 ての且歯部人工歯で観察した.

\section{2. 計測結果について}

1) 水平被蓋部分の面積変化

人工歯の摩耗が進行している長期間使用した義歯で は，咬煩や咬舌を生じることが多くなる。この原因とし て挙げられるのが水平被蓋の減少である。摩耗しても被 蓋が失われない人工歯形態を考える上で, 被蓋の消失傾 向を観察することは必要である. 試験前, 各人工歯の水 平被蓋部の面積は, アクリリックレジン歯より硬質レジ ン歯で大きい值を示した（図 7)。硬質レジン歯は層状 構造を有し, 各層の厚从が必要になることから煩舌径は 大きくなる傾向にあると考えられ, その結果, 硬質レジ ン歯の被蓋部面積が大きくなつたと推察された。試験回 数 $4 \times 10^{4}$ 回では H-Tr, H-En, A-Bi の面積は大きく, 他の人工歯に比較して有意差が認められた。 H-Tr, H-En，A-Bi， H-So は試験前の面積が十分に認められた

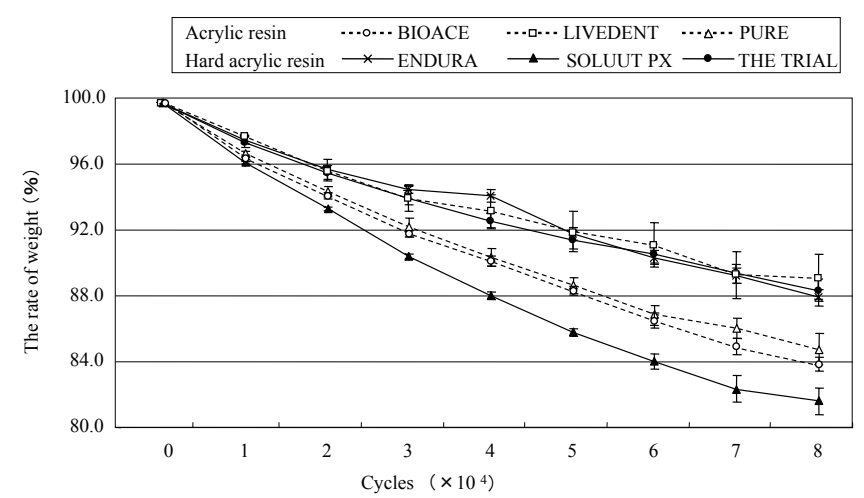

図 11 Duration of the weight of each artificial teeth by wear

摩耗による人工歯重量の経時的変化

表 2 Vickers hardness of artificial teeth

* : Referred to the value of the manufacturer making public

人工歯のビッカース硬度

\begin{tabular}{|c|c|c|}
\hline Materials & Products & $\mathrm{Hv}$ \\
\hline \multirow[t]{3}{*}{ Acrylic resin } & BioACE & * 20.5 \\
\hline & $\begin{array}{l}\text { LIVEDENT FB20 } \\
\text { Plastic } 100\end{array}$ & * 21.0 \\
\hline & Púre & * 20.5 \\
\hline \multirow[t]{3}{*}{ Hard acrylic resin } & ENDURA POSTERIO & * 29.6 \\
\hline & SOLUUT PX & * 45.0 \\
\hline & Trial & $34.5 \pm 2.3$ \\
\hline
\end{tabular}

が, H-So において試験回数 $4 \times 10^{4}$ 回まで他に比較し て大きく減少したため，H-Tr，H-En，A-Bi の面積が残 存した. H-So は摩耗量が大きく, 摩耗後に水平被蓋が 残存しにくい傾向にあると考えられた。試験回数 $7 \times$ $10^{4}$ 回以降では摩耗が極度に進行し, 臨床的に義歯が正 常に機能しうる状態とは考元難かった。被蓋部投影面積 の経時的変化より, 人工歯の多くは $2 \times 10^{4}$ 回まで面積 の急な減少を示し，その後は緩徐に推移した（図 8). 摩耗初期において上下顎人工歯は点接触しているが, 点 接触から面接触への移行時期において面積の急激な減 少が生じたものと考えられた。 A-Bi は試験前の面積は アクリリックレジン歯の中で最も大きく, 試験回数 $4 \times$ $10^{4}$ 回における減少率は最も少なかった（図 7,8，。 た H-Tr, H-En は試験前の面積が比較的大きく, 減少率 はA-Bi に次いで少なかった。 A-Bi は摩耗量が比較的大 きいが, 面積の減少率は最小であった。 H-Tr, H-Enは 
摩耗量が比較的少なく減少率も少ない傾向にあり，これ ら 3 種の人工歯は摩耗後にも水平被蓋が残存した。こ れには各人工歯形態が関与すると考えられた。臼歯部人 工歯には義歯装着時に水平被蓋が十分確保され，長期的 に維持されることが望まれる。この点において，上記の 人工歯は臨床的に好ましいと考えられた。

2）小窩裂溝の面積変化

咬合面に摩耗が生じると, 食物を粉砕する遁路として の機能が失われ，咀嚼能率の低下を招く。本研究では摩 耗の進行と共に小窩裂溝の面積が変化する様相を観察 し, 義歯の長期使用を目的とした咬合面形態を検討した。 試験前の各人工歯の小窩裂溝部面積は H-Tr が最も大き く，次いでH-En，A-Bi であった（図 9)。これには各 人工歯の咬合面の大きさが関与すると考えられた。すな わち，すべての人工歯の近遠心径は同一であるが，煩舌 径には差がある。この煩舌径の大きさの順と小召裂溝部 面積の順は同様であり, 小窩裂溝部面積が咬合面の大き さに影響したと考えられた。

本研究では咬合面間に磨材を介在させたため, 硬質レ ジン歯においても摩耗が進行した. $5 \times 10^{4}$ 回と $8 \times 10^{4}$ 回において, H-Tr, H-En の裂溝部面積の減少率は少な く，他に比較して有意差が認められた。特に H-Tr の裂 溝部面積は試験前および試験回数 1 ～ $3,8 \times 10^{4}$ 回に おいてすべての人工歯の中で最大であり, 減少率は少な かった（図 9，10）。本人工歯は耐摩耗性と咬合面形態 および小窩裂溝の保存を目的として開発されたもので ある。それゆえ，良好な計測結果が得られたと思われる。 これらの結果より, 充分な煩舌径が付与された人工歯で は，摩耗後に水平被蓋と小窩裂溝が保持される傾向にあ り, 義歯を長期に使用するうえで好ましいと考えられた。 臼歯部人工歯の煩舌径が増すと，義歯に作用する側方力 や義歯床下における負担圧配分，あるいは咀嚼能率など への影響も懸念される，それゆえ両者のバランスを考慮 した形態を臼歯人工歯に付与する必要があると考えら れた。

3）人工歯の重量変化と表面硬度

重量減少率は人工歯間において有意差が認められた。 また，一つの人工歯に着目すると，その比率は試験回数 に関わらずほぼ一定であった（図 11）。材質間における 減少率には明確な差が認められなかったが，これは硬度 の高い磨材を使用したことにより，表面硬度に関係なく 摩耗量の減少が生じたと考えられた（表 2)。この現象 は凝着摩耗と言われ，トライボロジーの領域における法 則，すなわち人工歯の硬度に反比例して ${ }^{4,5,17,32)}$ 摩耗が 進行したことが原因と考えられた。本研究では，すべて の人工歯において表面硬度に関係なく重量が経時的に
減少し，硬質レジン歯においてもアクリリックレジン歯 と同様に摩耗が認められた。水平被蓋部面積において, この摩耗量の減少傾向および表面硬度との間に関連は 認められず，摩耗量は大きいが被蓋部面積の減少は少な い人工歯や，摩耗量，被蓋部面積の減少量がともに少な い人工歯か認められた。小窩裂溝部面積の減少傾向に関 しても，表面硬度と摩耗量との間に関連は認められな かった。これらの結果より, 人工歯に摩耗が生じた後に 水平被蓋および小窩裂溝を長期的に保存するためには, 摩耗量が少なく, 摩耗前から大きい被蓋が存在し, 煩舌 径や裂溝が充分に付与されている形態が望ましいと考 えられた。

\section{V, 結 論}

本研究は摩耗後にも水平被蓋と小窩裂溝か確保され, 機能的形態が保持される人工歯について検証すること を目的として，アクリリックレジン歯 3 種，硬質レジ ン歯 3 種について水平滑走移動による摩耗試験を $8 \times$ $10^{4}$ 回まで行った。その結果，水平被蓋と煩舌径と小窩 裂溝が十分に付与されている人工歯が摩耗後にも水平 被蓋および小笠溝が長期的に保存されることが示唆 された。

\section{謝辞}

稿を終えるにあたり，終始御㤅篤なる御指導，御校閲 を賜りました本学歯学部歯科補綴学第一講座細井紀雄 名誉教授に深甚なる謝意を表します。また本研究の遂行 にあたり, 終始懇切なる御指導, 御鞭撻をいただきまし た大貫昌理博士に謹んで感謝の意を表しますとともに, 教室員各位に厚く御礼申し上げます。

\section{文献}

1) Ogle RE, Davis EL. Clinical wear study of three commercially available artificial tooth materials: thirtysix month results. J Prosthet Dent 1998; 79: 145-151.

2) Jooste C, Geerts G, Adams L. Comparison of the clinical abrasion resistance of six commercially available denture teeth. J Prosthet Dent 1997; 77: 23-27.

3) Ogle RE, David LJ, Ortman HR. Clinical wear study of a new tooth material: Part II. J Prosthet Dent 1985; 54: 67-75.

4）阿部泰彦, 山我貴之, 田地 豪ほか. 臼歯部硬質レジ ン人工歯の滑走摩耗に関する実験的研究。広大歯誌 1993; 25: 139-174. 
5）阿部泰彦. 而摩耗性を指標とした臼歯部人工歯材料の 選択基準に関する実験的研究. 広大歯誌 1993; 25: 121-138.

6) Koczorowski R, Włoch S. Evaluation of wear of selected prosthetic materials in contact with enamel and dentin. J Prosthet Dent 1999; 81: 453-459.

7）辻 喜之. 人工毛歯の咬耗に関する基礎的研究. 補経 誌 1982; 26: 63-70.

8) Ghazal M, Steiner M, Kern M. Wear resistance of artificial denture teeth. Int J Prosthodont 2008; 21: 166-168.

9) Stober T, Lutz T, Gilde $\mathrm{H}$ et al. Wear of resin denture teeth by two-body contact. Dent Mater 2006; 22: 243-249.

10）梅川義忠. エナメル質および金合金硬質レジン歯の摩 耗に与える影響. 日大歯学 2006; 80 (2) : 101-107.

11）梅川義忠, 永井栄一, 大谷賢二ほか. 硬質レジン歯の 耐摩耗性. 日歯医療管理誌 2006; 40: 274-279.

12）鈴木司郎。硬質レジンの耐磨耗性及び対合歯の磨耗性 について. 歯材器 $1997 ; 16 \cdot 29$ 回特別号 : 146.

13）鈴木司郎, 芝 燁彦, 安田 登ほか. 新しい硬質レジ ンの臨床への応用 (第 2 報) 耐摩耗性の検討。補綴誌 1986; 30: 1419-1425.

14）下山和弘, 内田達郎, 井上 篤ほか. 全部床義歯に使 用される臼歯部人工歯の選択基準と使用状況. 補綴誌 1995; 39: 643-648.

15）（株）アールアンドディ。歯科機器・用品年鑑 2008 年 版 (18 版). 名古屋：(株) アールアンドディ；2008, p.149-151.

16）細井紀雄, 椎名順朗, 大貫昌理. 全部床義歯補綴学模 型実習書. 神奈川: 鶴見大学歯学部歯科補綴学第一講座, 2007, p.41-44.

17）佐藤吉則, 永井栄一, 前島健吾ほか. 床用硬質レジン 歯に関する基礎的研究 (第 2 報) 臼歯の金属材に対する 耐摩耗性について。補綴誌 1991; 35: 331-338.

18）田原靖章，角 大輔，杉山哲也ほか. 新規人工歯の耐 摩耗性と被着色性について。補綴誌 112 回特別号 2004; 48: 92.

19）鶴田昌三, 國井 崇, 福井壽男ほか. アクリル - ウレタ
ン混合マトリックス型硬質レジン歯の歯科理工学的性 質. 愛院大歯誌 2000; 38: 285-288.

20) Suzuki S. In vitro wear of nano-composite denture teeth. J Prosthodont 2004; 13: 238-243.

21) Harrison A, Lewis TT. The development of an abrasion testing machine for dental materials. J Biomed Mater Res 1975; 9 (3): 341-353.

22）佐藤洋平, 大久保力廣, 細井紀雄ほか. 硬質レジン歯 の耐摩耗性に関する研究。鶴見歯学 2003; 29: 324.

23）志村一郎. 純チタンおよび各種人工歯材料の耐摩耗性 に関する研究。鶴見歯学 2001; 27: 45-58.

24）森川正朗．硬質レジン歯の各種人工臼歯に対する耐摩 耗性に関する基礎的研究. 日大歯学 1997; 71 (2) : 232-248.

25）山本 章. 歯牙咬耗面の形態学的機能的検討. 口病誌 1982; 49: 73-102.

26) 藍 稔. 切歯点部における咀嚼運動の解析. 補綴誌 1962; 6: 164-200.

27）田中慎二. 硬質レジン臼歯の咬耗に関する基礎的研究. 口病誌 1998; 65: 164-171.

28) Vergani CE, Giampaolo ET, Cucci AL. Composite occlusal surfaces for acrylic resin denture teeth. J Prosthet Dent 1997; 77(3): 328-331.

29）鈴木司郎, 田村文誉, 田中卓男. 新規人工歯の耐磨耗性. 補綴誌 107 回特別号 2002; 46: 61.

30）出口幹人, 長藤明博, 鈴木司郎。新規歯科用レジンの 耐衝撃性と耐摩耗性. 補綴誌 107 回特別号 2002; 46: 132.

31）鈴木司郎, 田中卓男, 平沼謙二. 人工歯の耐摩耗性及 び対合歯に対する研削性に関する研究. 補綴誌 96 回特 別号 1996; 40: 75.

32）村木正芳. 罒解トライボロジー 摩擦の科学と潤滑技 術. 東京：日刊工業新聞社出版；2007, p.81-86.

\author{
著者連絡先 : 千葉 ひかり \\ 干 230-8501 横浜市鶴見区鶴見 2-1-3 \\ TEL : 045-581-1001 \\ FAX : 045-573-9599 \\ E-mail : chiba-hikari@tsurumi-u.ac.jp
}




\title{
Influence of Wearing Artificial Teeth on Horizontal Overlap and Occlusal Surface Fissures
}

\author{
Hikari Chiba, DMD
}

Department of Removable Prosthodontics, Tsurumi University School of Dental Medicine

Ann Jpn Prosthodont Soc 1: 166-174, 2009

\begin{abstract}
Purpose: Artificial teeth that do not compromise masticatory function even after the teeth become worn are necessary to conserve the function of dentures for a long time. The purpose of this study was to observe the morphological changes of artificial teeth by wear, and to discuss the chronological changes of horizontal overlap and fissures.

Methods: Three types of acrylic resin teeth and three types of hard resin teeth were selected as specimens. Artificial teeth were arranged from the first premolar to the second molar, and a sliding test was performed using a mechanical wear testing device up to 80,000 cycles in water with sand at $37^{\circ} \mathrm{C}$. Every 10,000 cycles, the projected area of the horizontal overlap, fissure area, and weight were measured. The results $(n=5)$ were analyzed by two-way ANOVA/Tukey's test $(\mathrm{p}<0.05)$.

Results: No significant difference was found in the changes in horizontal overlap area between acrylic and hard resin teeth. Fissure area rapidly decreased up to 20,000 cycles, and there were significant differences among all the artificial teeth after 50,000 cycles. Also, with A-Bi, H-Tr and H-En, the horizontal overlap and the fissures were conserved after wear. The rate of decrease in tooth weight varied among the artificial teeth.

Conclusion: The results did not depend on the hardness of the artificial teeth. It is suggested that in artificial teeth that have sufficient horizontal overlap, bucco-lingual diameter and fissures, the horizontal overlap and fissures are conserved after wearing for a long time.
\end{abstract}

\section{Key words}

artificial teeth, abrasive test, horizontal overlap, pit and fissure, bite wound 